\title{
Fictions of Possibility: \\ Simulation for the Humanities from its History in the Technosciences
}

\author{
Willard McCarty* \\ King's College London, \\ 26-29 Drury Lane, London WC2B 5RL UK
}

Received 29.01.2016, received in revised form 13.05.2016, accepted 21.06.2016

Even a brief sketch of the history of simulation, given here for physics, climatology and biology, reveals from the perspective of the humanities possibilities for expansive and adventurous imaginative work. Despite the fact that simulation as we know it began its rapid and transformative growth with digital computing 70 years ago, it is only within the last decade that it has received critical attention in the humanities. Why this is so, given that simulation is so closely congruent with these disciplines, is a question worth pondering.

Keywords: simulation, history of technology, imagination, humanities.

DOI: 10.17516/1997-1370-2016-9-7-1553-1561.

Research area: culture studies.

Art, as though getting ready for an emergency, holds in steady readiness the intellectual equipment of creation in case (as seems now to be the case) there is a need to begin to look for and make recognizable the act of creating in the many other previously unacknowledged sites.... Art is our starting place.

Elaine Scarry, 'The made-up and the made-real' (1992)

\section{Introduction}

My subject is that polymorphic bundle of techniques we call 'simulation'. Simulation began at the end of World War II with digital computing, and by the end of the 1960s had spread throughout the social sciences. But it has remained almost unknown to the humanities, receiving minor critical attention only within the last decade. My aim here is to lay a suggestive basis for more and better critical attention to it.
Speaking from the perspective of the humanities, I will say what I think its potential is for these disciplines, drawing on its history in the sciences for evidence of simulation as an imaginative form. My argument will be that simulation is a way, a technological $\log o s$, for "imagining what you don't know" (McGann 2002) and in some cases cannot know in any other way.

Simulation is closely twinned with modelling, so I must say something at the

(C) Siberian Federal University. All rights reserved

* Corresponding author E-mail address: willard.mccarty@mccarty.org.uk 
outset about modelling itself, and so about 'model'.

The word 'model' is infamously polysemous and so requires some effort of definition. But the idea it points to is fundamental to scholarly thought, as the great Lithuanian sociologist Teodor Shanin has shown (Shanin 1972), and at the basis of all computing, hence largely unnoticed and therefore a topic of considerable importance. But 'model' isn't adequate, at least not for digital humanities. As mere hardware computers do nothing at all; as abstract formulations and their translations into code, neither do computational models. It's in the manipulating, in the enacting of the encoded model by hardware, that a model becomes a way of probing the known. Thus there are deep reasons for centering not on 'model' but on the recursive process of exploring an idea of something by manipulating a digitally operationalized representation of it, changing that representation as results dictate, manipulating the altered representation and so on. This process is what I mean by 'modelling' (McCarty 2005). My emphasis is not on engineering a stable representation, such as a mathematical model, but on the scholar's work in the recursion of use, rethinking and reengineering.

Simulation begins like modelling, with a model of something and software made from it. But unlike modelling, in which you isolate an aspect of that which you wish to study and subject that aspect to close analysis, simulation addresses systems that cannot be known merely from considering their parts in isolation complex systems (Jervis 1997). Simulation instead models the system itself, its components and dynamic structures, then turns this model loose to see what happens. It imitates what things do - but crucially not only allows for inventive play but invites it.

\section{Continuities of reasoning and practice}

The basic meaning of 'simulation' is traceable from primaeval ideas of similitude, analogy and figuration, its technical history from devices in antiquity used or specifically contrived as analogies to physical objects, their functions, processes and later the equations describing them. Unfortunately our common division of computing machinery into analogue (whose data varies continuously) and digital (which operates by discrete steps) has by a confusion of referents for 'analogue' obscured the fact that both kinds of hardware implement analogical reasoning, though in different ways. As a result 'the continuity of practice' they share has been obscured (Care 2012), and so our view of simulation's history blinkered.

The Oxford English Dictionary's earliest entry for 'simulation' in a positive sense doesn't help: it suggests that before the likely-seeming date of 1947 the word invariably meant deception, as it continued to do in other contexts. But a closer look reveals straightforward uses of the term in early $20^{\text {th }}$ Century descriptions of electrical circuits and of mechanics to simulate flight. There can be no question that de facto simulations - Babbage notably describes one in the Ninth Bridgewater Treatise (1837) - go back as far as one cares to look, but positive use of the word to denote them would appear to originate near the beginning of the last century. This usage became dominant with the growth of digital computing.

Nevertheless a redolence of deceit lingers, indeed is crucial to the total meaning of the word. Thus RAND scientist David G. Hays remarked that "What goes on in a simulation... is a sham and a pretense: imaginative play" (Hays 1965). On the one hand the analogical, figurative nature of simulation makes it troublesome to believers in strict, objectivist realism, for whom it stands in much the same dubious position as 
figurative, poetic language. On the other hand its technoscientific basis makes it equally disturbing to whose for whom such belief is the enemy. Its dependence on skill and tacit knowledge moves it away from the theoretical to the practical, gives it the ambiguous status of an art or craft - for one ecologist "more akin to making wine than building a machine" (Peck 2008). Comparison to artistic practice is commonplace.

The telling point is simulation's defining moment: when it becomes the only way to know something or to form a coherent picture from fragmentary knowledge. But at that point we must ask, what kind of knowledge does the inferential bridge of simulation offer? How far can we go without it crumbling? I will return to these questions.

\section{Continuity of intent}

Simulation was intellectually compelling from the outset. Rapid uptake into diverse contexts tempts us to look for a common aim or continuity of intent, which would be helpful for anticipating its usefulness to the humanities. But no one taxonomy fits the variety of applications: differences from discipline to discipline suggest distinct kinds, but the extensive crossdisciplinary traffic of borrowings cannot be ignored. Evelyn Fox Keller suggests following quasi-disciplinary lines of development while paying attention to the cross-talk (Keller 2003). I heed her advice as much as time will allow but attempt two shortcuts: an argument for a continuity of simulation's effect on the sciences, at which I have already hinted, and the continuity of intent I am about to venture.

Consider John von Neumann's preoccupations with a question that might be regarded as the oldest and most fundamental of all questions about simulation, namely, how closely can a mechanical simulacrum be made to resemble an organism? (Keller 2003) Among von Neumann's many distinctions we know him as the father of Artificial Life. Since then A-Life has become an attempt to demonstrate via in silico simulation that "life-as-we-know-it [can be located] within the larger picture of life-as-itcould be" (Langton 1989). But von Neumann's aim was different. In 1949, working on the cellular automata from which A-Life arose, he warned that, 'By axiomatizing automata in this manner, one has thrown half of the problem out of the window, and it may be the more important half'. We know from his final set of lectures (von Neumann 1958) that his ultimate target was that other half, the problem of simulating the human organism in its physical totality. Elsewhere I have argued that the implications for human self-understanding and the expressions of these in works of art and literature are central to the humanities. So it begins to look like simulation belongs. But it is an indefatigable trouble-maker.

\section{Cybernetics}

\section{and nuclear weapons research}

Between Turing's abstract analogical machine of 1936 and von Neumann's 1945 translation of it into a design for hardware (Turing 1936-7; von Neumann 1945), World War II intervened. The war-effort resulted in two research programmes important here: Norbert Wiener's cybernetics and nuclear weapons development.

First cybernetics. Wiener named the new science after the Greek word for 'steersman' (kubernētēs), whose intimate relationship with the tiller of a boat provides a telling metaphor of its aims (Wiener 1948). Cybernetics began in efforts to improve anti-aircraft artillery during World War II by integrating human with machine. It succeeded, but it also resulted in a comprehensive theoretical vision which for a time seemed to promise a universal science (Dupuy 2000). Cybernetics did far more than is 
usually remembered: it had deep and long-lasting influence, bringing together common interests in the medical, social, psychological and physical sciences toward an integrative view of the human. It provided a home for attention to kinaesthetic and cognitive human-machine integration in the fields of robotics, human-computer interaction and user-interface design. But I am getting ahead of myself.

Simulation began in earnest at the end of World War II with the application of digital computing by the United States to develop the atomic bomb, then to make possible the thermonuclear Super. As the historian of the Manhattan Project wrote, the physical scientists, mathematicians and engineers of the Project were initially stumped by phenomena "too far from the course of ordinary terrestrial experience to be grasped immediately or easily" (Hawkins 1946). These phenomena generated "problems too complex for theory and too remote from laboratory materials for experiment" (Galison 1996). So the scientists had to imagine what they did not know - by simulation based on analogy to the effectively random interactions of subatomic particles during a thermonuclear reaction. And so came about a decisive shift: "bit by bit (byte by byte) computer designers deconstructed the notion of a tool itself as the computer came to stand not for a tool, but for nature" (Galison 1996). We could say that the analogy was naturalized, but the point I wish to make is different: simulation proved itself very early in its history as a way of using what is known to imagine what is not and cannot otherwise be known.

Writing about the threat of annihilation created by nuclear weaponry, British military historian Lawrence Freedman comments that, "When faced with the possibility of nuclear war, an event for which there could be neither precedent nor experiment and which in its enormity challenged imagination, only simulation was possible" (Freedman 2013). Prominent American and British figures, such as Herman Kahn, argued for all manner of fantasies to be entertained and worked through in computer games simulating nuclear war and its aftermath (Ghamari-Tabrizi 2000). This happened, for example, at the U.S. RAND Corporation. In such a world it is not surprising that design for the first American civil defense system by a scientific committee of the U.S. Air Force, literally proposed a great anthropomorphic military cyborg (ADSEC 1950). The committee's report was taken seriously, adopted immediately and acted on. From its imaginings evolved in time the various forms of "a world-encompassing surveillance, communication and control system" (Edwards 2000), including Ronald Reagan's Strategic Defense Initiative, or "Star Wars". "The President's proposal did not seem bizarre to a public used to science fiction and conditioned by long exposure to Buck Rogers, Star Trek, and Darth Vader to regard outer space as a natural environment for war and counterwar", George Ball wrote in the New York Review of Books. "The President had told us that the Soviet Union is an 'evil empire' and he was now warning America that the 'empire' might 'strike back" (Ball 1985).

My point is not a political one nor about the Cold War. It is to notice that in the most serious of circumstances the most practical sort of people turned to simulation for what it does best and most often: not to provide certainty or proof but for stories of the possible future enacted in games.

Climatology provides a similar example. In the early years, as meteorologists extended their models to the globe, the lack of uniform, reliable data became a problem. Hence the computer was used to refine, correct and, PaulEdwards has noted, shape the data to fit the models (Edwards 1999). Again tool and nature blurred into each other. 
Thus the term 'scenario' entered climatology. As in other global sciences, it tells the familiar tale: of movement from the theory-like model that converges on and formalizes a singular, agreedupon understanding of an objective world to a narrative expressing the modeller's assumptions, interests and agenda. In consequence, Edwards has argued, "a different conception of the nature of scientific work" is required (1999). But how different? Ian Hacking's famous question, "Do we see through a microscope?" (Hacking 1983) suggests to me that simulation does not so much provoke a new question about knowledge as rewrite an old one. And so we ask, do we know when look with a simulation?

My last example is biology. We can take its central question - what is life? - to get straight to the point: are biological simulations alive? Keller suggests this may well turn out to be an historical, not a philosophical question (2003). So does Stefan Helmreich: he asks, "What was life?" (2011) before these simulations came along. If we recognize them as alive then we find ourselves alongside Dr Frankenstein, again with the question of the human. Thus simulation enters the humanities properly. Simulation is 'just a tool' if all it does is to produce more compelling representations that generate objects of study from rules in software. It is of the humanities when it becomes a tool for raising the questions humans ask about human things, and for bringing forth in cognitive psychologist Jerome Bruner's potent phrase "the alternativeness of human possibility" (1986).

\section{Simulation in the humanities}

In the humanities modelling is not really a problem once it is understood: the analogical bridge between computing and the interpretative disciplines keeps the digital construct separate, informing humanistic research both by what it discovers and especially by what it cannot.
Simulation is a different matter, far more of a troublemaker. To date the most successful research in the interpretative disciplines continues to be with social or physical things (like populations or books) whose behaviour can plausibly be generated by computational agents operating according to simple rules. This is known in the trade as "agent-based modelling" (Troitzsch 2009). Archaeological and historical reconstructions, which simulate the experience of being in a vanished or ruined site, are now quite popular. I do not want to gainsay their value nor the value of agent-based modelling to the social sciences and humanities. But all these face a serious limiting condition: the current limits of artificial intelligence. In the recent words of an archaeologist, these simulations fall short because "we do not yet know how to model human cognition on a computer in other than relatively superficial and oversimplified ways" (Doran, q. Düring 2014).

But there's much more to learn from gaming, or by its proper name in the humanities, serio ludere, "serious play" (Berger 1988).

In 1984 English teacher Edward Versluis pointed to the "emotionally rich thinking experience" of such play, citing the notable ability of Joseph Weizenbaum's psychoanalytic simulation Eliza to induce what Weizenbaum called "powerful delusional thinking" in those who submitted themselves to the simulated analyst (Weizenbaum 1976). Versluis imagined an Eliza reconfigured in the service of teaching and research, delusion reconceived as imaginative fantasy exercised in order to elicit and make real that "alternativeness of human possibility".

Eliza's quite surprising power was not the result of sophisticated artificial intelligence first-year computer science students write such things today as an exercise - rather the product of a non-autonomous, cooperative humanmachine simulation. Like all simulation it was 
a trick, but it is also a clue to what could be done. A similar set of ideas about computerhuman cooperation underlies experiments like Jerome McGann's Ivanhoe Game, which teasingly suggests what might be done. In this game human players make algorithmic changes to a shared text as a way of exploring the effects of those changes on the literary ecology of text and reader (McGann 2014). The Ivanhoe Game simulates criticism as a social activity.

\section{A concluding example}

Let me end with a current example chosen for the clarity of its dilemma: literary scholar John Wall's Virtual Paul's Cross (Wall 2014). This simulation digitally re-creates the English poet and divine John Donne's sermon of 5 November 1622 celebrating the failure of the plot 17 years earlier to blow up the British Parliament with King James I attending. Virtual Paul's Cross recreates the encompassing world of this event: the improvisational performance for which Donne was noted, spoken by an accomplished actor; the distractions of a $17^{\text {th }}$ century outdoor gathering - social interactions, dogs, horses and the many unsynchronized bells of nearby churches ringing cumulatively on the quarter-hour; and as much as can be known or conjectured about the physical environment adjacent to St Paul's. Much is uncertain, some evidence contradictory. The structures of stones, timbers, plaster, tiles, metal and glass perished in the Great Fire of 1666. Four centuries of social change and urban development far less reverent of the past than we are have intervened. Even the location is uncertain: the printed edition, sole evidence published years after Donne's death, declares that contrary to normal practice the sermon took place inside the Cathedral because of rain. Virtual Paul's Cross enacts it outside, where Donne intended it to be.
You may wonder whether such a reconstructive simulation, implementing analogies to a past so imperfectly known, amounts to no more than an entrancing deception. It is a deception. But it is much more than that once we put the kinds of conjectures that it offers us in the context of simulation. The history I have briefly recounted argues that the kind of counterfactuality or misleadingness deployed by Virtual Paul's Cross must be understood, in Evelyn Fox Keller's words, as “a positive virtue, not a negative one... [which makes] possible that 'willing suspension of disbelief' that permits uncertainty to remain out of focus, that allows the 'as if' to do the remarkable work it has so often done in the past" (2002).

\section{Conclusion}

We are left, then, not just with big ideas but with big questions and projects, concerning the roles these two fundamental things you can do with a computer - modelling and simulating - play or are to play in our practices of enquiry, how we are to become self-aware practitioners of them and how they change these practices and are changed by them. '[T] he use of computers', Fr Roberto Busa wrote in 1976, 'is not aimed towards less human effort, or for doing things faster and with less labour, but for more human work, more mental effort...' (Busa 1976). The question is, to what is that effort directed? Not, as modelling and simulating both make clear, what the bereaved call 'closure' but (once again) Bruner's 'alternativeness of human possibility', William Blake's 'expanding eyes'. Simulation returns us to Aristotle's function of poetry (Poetics 1451b), to describe not the thing that has happened (genómena) but a kind of thing that might happen (génoito), something more philosophical and worthy of serious attention, he thought, even than history. 


\section{References}

ADSEC. 1950. The Air Defense System. Final report of the Air Defense Systems Engineering Committee, 24 October 1950. https://archive.org/search.php?query=adsec.

Ball, G. W., 1985. The War for Star Wars. New York Review of Books (11 April).

Berger, H., Jr., 1988/1969. Pico and Neoplatonist Idealism: Philosophy as Escape. In: Second World and Green World: Studies in Renaissance Fiction-Making. Ed. J. P. Lynch. Berkeley CA: University of California Press. pp. 198-228.

Bruner, J., 1986. Possible Castles. Actual Minds, Possible Worlds. Cambridge MA: Harvard University Press. p. 44-54.

Busa, R., S.J., 1976. Why can a computer do so little? Bulletin of the Association for Literary and Linguistic Computing 4(1), pp. 1-3.

Care, C., 2012. Early computational modelling: Physical models, electrical analogies and analogue computers. In C. Bissell and C. Dillon, eds. 2012. Ways of Thinking, Ways of Seeing: Mathematical and other Modelling in Engineering and Technology. Berlin: Springer-Verlag. pp. 95-119.

Dupy, J.-P., 2000/1994. The Mechanization of the Mind: On the Origins of Cognitive Science. Trans. M. B. DeBevoise. Princeton: Princeton University Press.

Düring, M., 2014. The Potential of Agent-Based Modelling for Historical Research. In P. A. Youngman and M. Hadzikadic, eds. 2014. Complexity and the Human Experience: Modeling Complexity in the Humanities and Social Sciences. Boca Raton FL: Pan Stanford Publishing. pp. 121-37.

Edwards, P.N., 1999. Global Climate Science, Uncertainty and Politics: Data-laden Models, Model-filtered Data. Science as Culture 8(4), pp. 437-72.

Edwards, P. N., 2000. The World in a Machine: Origins and Impacts of Early Computerized Global Systems Models. In T. P. Hughes and A. C. Hughes, eds. 2000. Systems, Experts, and Computers: The Systems Approach in Management and Engineering, World War II and After. Cambridge, MA: MIT Press. pp. 221-54.

Freedman, L., 2013. Strategy: A History. Oxford: Oxford University Press.

Galison, P., 1996. Computer simulations and the trading zone. In P. Galison and D. J. Stump, eds. 1996. The Disunities of Science: Boundaries, Contexts, and Power. Stanford CA: Stanford University Press. pp. 118-57.

Ghamari-Tabrizi, S. 2000. Simulating the Unthinkable: Gaming Future War in the 1950s and 1960s. Social Studies of Science 30(2), pp. 163-223.

Hacking, I., 1983. Representing and Intervening: Introductory Topics in the Philosophy of Natural Science. Cambridge: Cambridge University Press.

Hawkins, D., 1946. Inception until August 1945. In: Manhattan District History. Project Y. The Los Alamos Project. Vol. 1. LAMS-2532. Los Alamos NM: Los Alamos Scientific Laboratory.

Hays, D. G., 1965/1962. Simulation: An introduction for anthropologists. In: D. Hymes, ed. 1965. The Use of Computers in Anthropology. The Hague: Mouton \& Co. pp. 402-26.

Helmreich, S., 2011. What was Life? Answers from Three Limit Biologies. Critical Inquiry 37(4), pp. 671-96.

Jervis, R., 1997. System Effects: Complexity in Political and Social Life. Princeton NJ: Princeton University Press. 
Keller, E. F., 2002. Synthetic biology redux - Comptuter simulation and artificial life. In Making Sense of Life: Explaining Biological Development with Models, Metaphors, and Machines. Cambridge MA: Harvard University Press. pp. 265-94.

Keller, E. F., 2003. Models, Simulation, and 'Computer Experiments'. In H. Radder, ed. 2003. The Philosophy of Scientific Experimentation. Pittsburgh PA: University of Pittsburgh Press. pp. 198-215.

Langton, C. G., 1989/1987. Artificial Life. In C. G. Langton ed. 1989. Artificial Life. Proceedings of an Interdisciplinary Workshop on the Synthesis and Simulation of Living Systems held September, 1987 in Los Alamos, New Mexico. Vol VI. Santa Fe Institute, Studies in the Sciences of Complexity. Redwood City CA: Addison-Wesley. pp. 1-47.

McCarty, W. (2005). Humanities Computing. Houndmills, Basingstoke: Palgrave.

McGann, J. (2002). Radiant Textuality: Literature after the World Wide Web. Palgrave, New York.

McGann, J., 2014. A New Republic of Letters: Memory and Scholarship in the Age of Digital Reproduction. Cambridge MA: Harvard University Press.

Peck, S. L., 2008. The hermeneutics of ecological simulation. Biology and Philosophy 23, pp. 383-402.

Scarry, E., 1992. The Made-Up and the Made-Real. Yale Journal of Criticism 5(2), pp. 239-49.

Shanin, T. 1972. "Models and Thought". In The Rules of the Game: Cross-disciplinary Essays on Models in Scholarly Thought. Ed. Teodor Shanin. 1-22. London: Tavistock Publications

Troitzsch, K. G., 2009. Multi-Agent systems and simulation: A survey from an application perspective. In A. M. Uhrmacher and D. Weyns, eds. 2009. Multi-Agent Systems: Simulation and Applications. Boca Raton FL: CRC Press. pp. 53-75.

Turing, A. 1936. On Computable Numbers, with an Application to the Entscheidungsproblem. Proceedings of the London Mathematical Society, ser. 2, 42 (1936-7): 230-65.

Versluis, E. B., 1984. Computer Simulations and the Far Reaches of Computer-Assisted Instruction. Computers and the Humanities 18(3-4), pp. 225-32.

von Neumann, J. 1945. First Draft of a Report on the EDVAC. Contract W-670-ORD-4926, U.S. Army Ordnance Department and the University of Pennsylvania. Philadelphia PA: Moore School of Electrical Engineering. Rpt. IEEE Annals of the History of Computing 15.4 (1993): 27-43.

von Neumann, J., 1958. The Computer and the Brain. New Haven: Yale University Press.

Wall, J. N., 2012. Recovering Lost Acoustic Spaces: St. Paul's Cathedral and Paul's Churchyard in 1622. Digital Studies / Le champ numérique 4. [online] Available at: <www.digitalstudies.org/ojs/ index.php/digital_studies> [Accessed 12 August 2015].

Weizenbaum, J., 1976. Computer Power and Human Reason: From Judgment to Calculation. New York: W. H. Freeman and Company.

Wiener, N., 1948. Cybernetics, or Control and Communication in the Animal and the Machine. Cambridge MA: The Technology Press, MIT. 


\title{
Невероятные возможности: \\ история симуляции \\ от технических наук к гуманитарным
}

\author{
Уиллард МакКарти \\ Королевский колледж Лондона \\ Соединенное Королевство, \\ Лондон WC2B 5RL, Друри Лэйн 26-29
}

Даже краткий обзор истории симуляции, разработанной для физики, климатологии и биологии, открывает перспективы ее использования в гуманитарных науках для расширения возможностей работы воображения. Несмотря на то, что симуляиия, какмы ее знаем, начала стремительно развиваться в программировании 70 лет назад, в области гуманитарных наук пристальное внимание ей стало уделяться только в последние годы. Почему так сложилось, учитывая, что симуляция тесно переплетается с этими дисциплинами, -хорошая тема для размышлений.

Ключевые слова: симуляция, история технологий, воображение, гуманитарные науки.

Научная специальность: 24.00.00 - культурология. 